\title{
PENDEKATAN INWARD EXPERIENCE DAN OUTWARD BEHAVIOUR SEBAGAI TAWARAN MODEL UNTUK KAJIAN AGAMA
}

\author{
Hammis Syafaq \\ Universitas Islam Negeri Sunan Ampel Surabaya, Indonesia \\ E-mail: hammissyafaq@yahoo.com
}

\begin{abstract}
This paper deals with the importance of inward experience and outward behavior in religious studies. The reason underlying this paper is that what insiders perform cannot be felt by outsiders. Experiences felt by practicing insiders constitute the internal aspect of religion which cannot be communicated to others; therefore it cannot be transferred to outsiders. This characteristic is often misunderstood by many observers of religion, and this leads to the gap between insiders and observers, particularly when the latter's faith is different from that of former. This constitutes the major problem in the study of religion nowadays despite the fact that there have been progresses made by scholars in regard to empathic approach in the study of religion. The purpose of this approach is to bridge the gap between insiders and outsiders, while offering an understanding that insiders' experiences can be called inward experience, while external behavior grasped by outsiders is called outward behavior. By doing so, prejudices and lurking attitudes among different religious believers can be avoided.
\end{abstract}

Keywords: Inward experience, outward behaviour, religious studies.

\section{Pendahuluan}

Dalam ajaran Islam terdapat berbagai petunjuk tentang bagaimana seharusnya umat Islam menyikapi hidup dan kehidupan secara lebih bermakna. Islam juga mengajarkan model kehidupan yang dinamis dan progresif; bersikap seimbang dalam memenuhi kebutuhan material dan spiritual; senantiasa mengembangkan kepedulian sosial, bersikap terbuka, berorientasi pada kualitas, egaliter, kemitraan, dan mencintai sesama dan mengutamakan persaudaraan. 
Realitanya, umat Islam lebih suka memahami agamanya secara teologis dan normatif; lebih berorientasi pada aspek legal formal praktik keagamaan daripada aspek kebermanfaatan agama; dan lebih menekankan pada aspek kuantitatif penggunaan simbol-simbol keagamaan daripada aspek kualitatif keberagamaan pemeluknya. Hal ini terbukti dengan kondisi keumatan dalam masyarakat Islam yang masih berada dalam ketersekatan.

Di dalam sejarah pemikiran Islam klasik, umat Islam sudah terpecah menjadi beberapa sekte, seperti Mu'tazilah, Ash'arîyah, dan Mâtûridîyah, dan lain-lain, ${ }^{1}$ yang masing-masing dari pemikiran itu menyuguhkan bentuk Islam yang berbeda dan terkadang saling menyalahkan satu sama lainnya. ${ }^{2}$ Dalam pandangan Fahmî Huwaydî, seorang sarjana Muslim dari Mesir, pemahaman keagamaan yang semacam ini disebut dengan istilah al-tadayyun al-manqûs. (keberagamaan yang terdegradasi). ${ }^{3}$

Kini model pemikiran itu masih berlanjut, dan umat Islam masih mengidolakan beberapa model pemikiran teologis di atas. Bahkan, dalam kajian teologi, beberapa model pemikiran di atas masih menjadi tolok ukur untuk penilaian keberagamaan seseorang. Padahal, yang terpenting dalam beragama bukanlah penampilan simbol keagamaan di permukaan, tetapi bagaimana agama itu dapat dirasakan dalam kehidupan seseorang.

M. Amin Abdullah pada acara AICIS (Annual International Conference on Islamic Studies) XIV menyebut model pemikiran teologis-normatif ini dengan istilah al-fiker al-lâhûtî al-siyâsî (pemikiran teologis-politis). Menurut Amin, model pemikiran semacam ini melihat keagamaan orang lain secara normatif sesuai dengan cara pandangnya sendiri; mereka memiliki fanatisme yang berlebihan terhadap kelompoknya, atau memiliki loyalitas, komitmen, dan dedikasi yang kuat terhadap kelompoknya sendiri, serta menggunakan bahasa yang bersifat subjektif; mereka juga menganggap pemahamannya sebagai satu-satunya kebenaran yang mutlak, ${ }^{4}$

\footnotetext{
${ }^{1}$ Harun Nasution, Teologi Islam (Jakarat: UI Press, 1978), 32.

2 Hammis Syafaq, "Masyarakat Muslim Indonesia dan Pembentukan Ideologi Perekat Umat", Akademika: Jurnal Studi Keislaman, Vol. 14, No. 2 (Maret 2004), 6576.

${ }^{3}$ Fahmi Huwaydî, al-Tadayyun al-Manqûs (Kairo: Dâr al-Shurûq, 1997).

${ }^{4}$ M. Amin Abdullah, "The Intersubjective Type of Religiousity: A Contribution (a Fresh Ijtihad) of Indonesian Islamic Studies to a Multicultural Society", Makalah
} 
sehingga sangat mudah terpancing untuk menyalahkan orang lain yang berbeda. ${ }^{5}$

Tidak jarang juga model pemahaman semacam ini menuduh kelompok lain yang berbeda sebagai kelompok sesat, kafir, dan ahli bid'ah. Mereka menilai kebenaran keberagamaan seseorang melalui penampilan eksternal dari ritual formal yang dilakukan. Mereka juga mmiliki pemahaman agama yang literal, ${ }^{6}$ dan cenderung untuk menyakralkan pemikiran keagamaannya (taqdîs afkâr dînîhim). Pun mereka menegasikan ajakan berdialog (ghayr qâbil li al-niqâsh). ${ }^{7}$ Antara satu kelompok dengan yang lainnya tidak saling menghargai, karena masing-masing bersikap eksklusif dan fanatis. ${ }^{8}$ Konflik Sunnî-Shî‘ah pun lahir dari model pemahaman teologis-normatif ini.

Pendekatan teologis ini selalu menggunakan cara berpikir deduktif dalam memahami agama, yaitu cara berpikir yang berawal dari keyakinan yang diyakini benar dan mutlak adanya, karena ajaran yang berasal dari Allah sudah pasti benar. Pemikiran seperti ini dimulai dari suatu keyakinan yang selanjutnya diperkuat dengan dalil-dalil dan argumentasi. Pendekatan ini memunculkan militansi beragama dan berpegang teguh pada ajaran agama. Pendekatan teologis ini berkait erat dengan pendekatan normatif, yaitu suatu pendekatan yang memandang agama dari segi ajarannya yang pokok dan asli dari Allah, yang di dalamnya tidak terdapat penalaran pemikiran manusia.

Dari hasil beberapa penelitian di Indonesia, konflik keagamaan, konflik berbasis SARA (Suku, Agama, dan Ras), ledakan bom di Gereja Bethel Injil Sepenuh (GBIS) Kepunton Solo, ${ }^{9}$ konflik antara Sunnî-Shî‘ah di Jawa Timur, konflik Sunnî-Ahmadîyah di Jawa Barat, dan penolakan FPI kepada Ahok untuk menjadi Gubernur Jakarta adalah dampak dari model keberagamaan yang teologis-normatif semacam ini. Melihat model keberagamaan orang lain melalui perspektif dirinya dan tidak mau melihat model keberagamaan orang

dipresentasikan pada Plenary Session acara AICIS XIV di Samarinda, November 21-24, 2014.

5 Syafaq, "Masyarakat Muslim Indonesia", 65-76.

${ }^{6}$ Abuddin Nata, Metodologi Studi Islam (Jakarta: Raja Grafindo Persada, 2003), 28.

7 Muhammad Arkûn, al-Islâm: al-Akhlâq wa al-Siyâsah, terj. Hâshim Sâliḥ (Beirut: Markaz al-Inmâ' al Qawmî, 1990), 172.

${ }^{8}$ Nasution, Teologi Islam, 32.

${ }_{9}^{9}$ Wasid Mansyur, Menegaskan Islam Indonesia (Surabaya: Pustaka Idea, 2014), 53. 
lain melalui perspektif pelakunya, yang dalam bahasa Amin Abdullah, disebut dengan insider perspective. ${ }^{10}$

Di sinilah, menurut Muhammad Saî̀d al-'Ashmâwî, letak problem dalam kajian agama, di mana ketika umat Islam lebih banyak berpedoman pada keyakinan daripada tataran metode ilmiah, lebih banyak bersandar pada emosi (intuisi) daripada rasio. Sikap inilah yang melahirkan aksi-aksi teror dan masalah takfir (tuduhan kafir terhadap seseorang). ${ }^{11}$ Apa yang diungkapkan oleh al-'Ashmâwî ini cukup beralasan karena pendekatan teologis yang digunakan oleh pemeluk agama bersangkutan memunculkan aliran-aliran kalam yang dogmatis.

Oleh karena itu, memahami Islam dengan menggunakan pendekatan teologis semata tidak dapat memecahkan masalah esensial model keberagamaan umat Islam saat ini. Terlebih lagi kenyataan mengungkapkan bahwa kemunculan pemikiran teologis tidak pernah lepas dari jaringan institusi atau kelembagaan sosial masyarakat yang ada di sekitarnya. Kepentingan ekonomi, sosial, dan politik selalu menyertai pemikiran teologis yang sudah mengelompok dan mengristal dalam satu komunitas masyarakat tertentu.

Tentunya, dalam melihat model keberagamaan, seorang outsider (pengamat) tidak berangkat dari sebuah keyakinan sebagaimana yang dimiliki oleh insider (pelaku), ${ }^{12}$ sehingga hasil interpretasinya seringkali tidak sesuai dengan keyakinan insider. ${ }^{13}$ Seorang outsider dalam melakukan studi terhadap perilaku keagamaan orang lain tidak terlalu mendalam, karena tidak memahami aspek sesungguhnya dari perilaku keagamaan yang dilakukan oleh pelakunya. Seorang outsider hanya melihat aspek eksternal perilaku keagamaan orang lain yang berbeda dengan sudut pandangnya.

Perspektif outsider yang hanya melihat aspek eksternal inilah yang menjadi salah satu problem dalam studi Islam yang dilakukan oleh kalangan non-Muslim, seperti orientalis Barat (outsider), dalam mengkaji Islam. Kajian mereka tentang Islam tidak berangkat dari sebuah keyakinan, sebagaimana yang dilakukan oleh kalangan Muslim (insider). Kajian mereka tentang Islam dilakukan dengan menggunakan

${ }^{10}$ Abdullah, "The Intersubjective Type of Religiousity".

11 Muhammad Saî̀d al-'Ashmâwî, Min Waby al-Qalam (Kairo: Dâr al-Macârif, 1997), 98-99.

${ }^{12}$ Hisham Sharabi, "The Scholarly Point of View: Politics, Perspective, Paradigm”, dalam Hisham Sharabi (ed.), Theory, Politics, and the Arab World (New York: Routledge, 1990), 1.

${ }^{13}$ Edward W. Said, Covering Islam (New York: Pantheon Books, 1981), 154-155. 
teori dan metodologi yang mereka miliki, ${ }^{14}$ dari hasil yang mereka ciptakan, ${ }^{15}$ sehingga hasil interpretasinya terhadap perilaku keagamaan masyarakat Muslim seringkali tidak sesuai dengan keyakinan kalangan umat Islam, dan miskin akan discourse of analysis.

Di sinilah pentingnya kajian ini dilakukan sebagai upaya untuk keluar dari sikap sempit ilmu, yaitu sikap yang dapat menyebabkan terpisahnya seorang ilmuan dari ilmuan lainnya karena tidak mampu menghadirkan sebuah pemahaman yang holistik dari peristiwa yang terjadi di masyarakat Muslim. Sikap seperti ini dapat menyebabkan penyudutan objek kajian, gambaran yang sepotong dan tidak menyeluruh terhadap model keberagamaan seseorang.

Salah satu contoh yang dapat dijadikan sebagai salah satu kasus untuk dimunculkan di sini dalam rangka menjelaskan sempitnya model pemahaman sarjana Barat adalah beberapa kajian yang mereka lakukan tentang fundamentalisme Islam. Kajian mereka tampak sangat simplifikatif, membosankan, dan berputar-putar di sekitar Islam sebagai oknum yang bertanggung jawab atas semua peristiwa terorisme yang terjadi di beberapa belahan bumi ini. Padahal, di sana ada beberapa faktor lain yang menjadi aktor utama dari peristiwa terorisme itu, yaitu faktor sosial, politik, ekonomi, dan lain sebagainya.

Para sarjana Barat itu, sebagai outsider, tidak merasakan apa yang dirasakan oleh pelaku terorisme sebagai insider, sehingga tidak mampu memahami secara utuh tentang perilaku terorisme itu. Jadi, ada perasaan berbeda antara pelaku keagamaan (believer) dan orang lain. Yang pertama mempertahankan pemahaman normatif dari perilaku keagamaannya secara subjektif dan fideistic dengan menilai orang lain benar atau salah karena melihatnya dari sisi teologis. Sementara yang kedua (orang lain) hanya melakukan penilaian dari apa yang dilihatnya. Kondisi inilah yang seringkali melahirkan ketegangan.

Untuk itu penulis tertarik untuk menawarkan model baru dalam kajian agama agar dunia Islam dapat berkomunikasi dengan komunitas lain secara baik. Memahami dengan "kaca pandang" baru apa yang dimaksud dari agama dan beragama. ${ }^{16}$ Karena memahami agama itu tidak hanya melalui pintu wahyu belaka, tetapi juga bisa

${ }^{14}$ Sharabi, "The Scholarly Point of View", 1.

15 Said, Covering Islam, 154-155.

16 Penjelasan tentang makna beragama dan agama diungkapkan oleh M. Amin Abdullah, "Kata Pengantar", dalam Richard Martin, Pendekatan Kajian Islam dalam Studi Agama, terj. Zakiyuddin Baidhawy (Surakarta: Muhammadiyyah University Press, 2001), iii-ix. 
dipahami melalui pintu pemeluknya, yaitu masyarakat Muslim yang menghayati, meyakini, dan memperoleh pengaruh dari Islam tersebut.

\section{Perkembangan Model Pendekatan dalam Studi Agama}

Kalau dilacak, sejarah pertumbuhan studi Islam dapat dilihat pada abad ke-19, di mana kajian Islam pada masa ini lebih menekankan pada tradisi filologi. Para pengkaji di bidang ini adalah dari kalangan pakar bahasa, ahli teks-teks kunci klasik, yang melalui bahasa dan teks klasik itu mereka dapat memahami gagasan-gagasan dan konsepkonsep utama yang membentuk umat Islam, tanpa memahami konteks. ${ }^{17}$

Kajian Islam melalui pendekatan filologis ini memiliki keterbatasan, di antaranya adalah penekanannya yang eksklusif terhadap teks. Dunia Islam dipahami melalui cara tidak langsung, tidak dengan melakukan penelitian tentang kehidupan masyarakat Muslim yang ada di masyarakatnya, tetapi melalui prisma teks yang umumnya berasal dari tradisi intelektual klasik Islam. Kajian ini berfokus pada tulisan-tulisan Muslim, bukan pada Muslimnya sendiri. ${ }^{18}$ Pendekatan ini sangat membantu dalam membuka kekayaan daftar materi keislaman dari dokumen-dokumen lama, karena melakukan studi tehadap Islam tanpa menguasai Bahasa Arab adalah sebuah kemustahilan.

Pada masa berikutnya, para pengkaji mulai menyadari kelemahan kajian filologi ini, sehingga muncullah kajian sains. Para penganjur pendekatan ke dua ini berpendapat bahwa kajian tentang masyarakat harus diupayakan melalaui metode-metode sains seperti yang dipahami oleh ilmuwan sosial. Pendekatan ini berdasarkan pada sebuah keyakinan bahwa semua masyarakat akan mengalami proses perkembangan historis. Pendekatan ini memiliki perhatian yang lebih pada fungsi daripada bentuk-bentuk atau muatan kultural dari institusi sosial. Makna dan muatan kultural dari institusi sosial tidak relevan dan dikesampingkan. Menurut pendekatan ini, masyarakat bukanlah sistem makna, tetapi mesin sosial.

Jika merujuk pada tulisan Eric J. Sharpe, ditemukan adanya dua model pendekatan yang paling populer digunakan oleh para pengkaji

17 Noor Chozin Askandar, "Pendekatan dalam Studi Islam", Makalah Kelas Program Doktor IAIN Sunan Ampel Surabaya, angkatan 2003.

18 Zakiyuddin Baidhawy, "Perkembangan Kajian Islam dalam Studi Agama", dalam Richard Martin, Pendekatan Kajian Islam dalam Studi Agama, terj. Zakiyuddin Baidhawy (Surakarta: Muhammadiyyah University Press, 2001), xi-xxv. 
Agama, yaitu fideistic subjectivism/al-'aql al-dîñ̂ al-lâbûtî̀ (pemikiran teologis-normatif), dan scientific objectivism / al-'aql al-falsafì (pemikiran filsafat). ${ }^{19} \quad$ Pendekatan fideistic subjectivism/al-'aql al-dîn $\hat{\imath}$ allâhûtî/pemikiran teologis-normatif berupaya memahami agama secara literal. Menggunakan kerangka ilmu Ketuhanan yang bertolak dari suatu wilayah keyakinan. Loyalitas yang tinggi terhadap kelompok sendiri. Cenderung mengklaim pemahamannya yang paling benar, serta penggunaan bahasa yang bersifat subjektif. Sementara pendekatan kedua (scientific objectivism/al-'aql al-falsafi/pemikiran filsafat) berupaya memahami agama melalui pendekatan sejarah berbagai peristiwa, dengan memperhatikan unsur tempat, waktu, objek, latar belakang dan pelaku dari peristiwa tersebut. ${ }^{20}$

Logika berpikir pendekatan pertama selalu menggunakan model deduktif, yaitu cara berpikir yang berawal dari keyakinan untuk selanjutnya diperkuat dengan dalil-dalil dan argumentasi. Pendekatan ini memunculkan sikap militansi dalam beragama dan berpegang teguh pada ajaran agama. Di antara pendekatan-pendekatan yang berdekatan model pertama ini adalah missionary approach, apologetic approach, dan irenic approach. ${ }^{21}$

Pendekatan missionary approach bermula dari terjadinya booming misionaris sebagai serpihan dari umat, sekte, dan gereja Kristen, bersamaan dengan pertumbuhan pengaruh politik, ekonomi dan militer di Asia dan Afrika pada abad ke-19. Langkah-langkah yang ditempuh dalam pendekatan ini adalah misi keimanan (faith mission). Sementara apologetic approach memiliki karakteristik apologis. Kecenderungan untuk membanggakan kemampuan Islam untuk menjawab semua tantangan di tengah perkembangan masa modern. Menjadikan masa lalu sebagai solusi untuk semua masalah, dan berusaha untuk keluar dari tekanan peradaban Barat. Sedangkan irenic approach merupakan upaya orang-orang Barat untuk membangun simpati (mutual sympatby) antara tradisi-tradisi agama dan bangsa. Pendekatan ini muncul seiring dengan semakin dewasanya gerakan keagamaan maupun keilmuan di Barat sejak tahun-tahun awal perang dunia kedua. ${ }^{22}$

${ }^{19}$ Eric J. Sharpe, Comparative Religion of History (London: Duckworth, 1986), 313.

20 Taufik Abdullah, Sejarah dan Masyarakat (Jakarta: Pustaka Firdaus, 1987), 105.

${ }^{21}$ Charles J. Adams, "Islamic Religious Tradition", dalam Leonard Binder (ed.), The Study of the Middle East: Research and Scholarship in the Humanities and the Social Science (New York: A Wiley-Interscience Publication, 1976).

${ }^{22}$ Ibid. 
Dengan demikian pendekatan atau metode dalam memahami Agama terus mengalami perkembangan sesuai dengan temuan-temuan yang didapat oleh pemeluk suatu Agama. Pendekatan itu sangat penting karena ia terkait dengan cara pandang atau paradigma pada suatu bidang ilmu yang digunakan untuk memahami Agama. ${ }^{23}$ Studi tentang data keagamaan, seperti al-Qur'ân, teks-teks klasik, dan interpretasi tentang makna-makna keagamaan, jika pendekatan dan metode yang digunakan berbeda, maka kesimpulan-kesimpulan ilmiahnya juga cenderung berbeda. Hal inilah yang akan membantu kita bersikap arif dalam melihat model keberagamaan orang lain karena mereka memiliki pendekatan yang berbeda.

\section{Pendekatan Inward Experience dan Outward Behaviour dalam Kajian Agama}

Sebagai penjelasan awal untuk istilah inward experience dan outward behaviour ini, penulis mulai dari pernyataan 'Âmir al-Najjâr, salah seorang pengkaji dan pengamal ajaran tasawuf, yang mengatakan bahwa pengalaman yang dirasakan dalam mengamalkan ajaran tasawuf tidak dapat dikomunikasikan kepada orang lain. Pengalaman itu sangat internal, berada di bagian terdalam diri manusia. Pengalaman itu tidak dapat dijelaskan melalui bahasa tulis maupun lisan. Pengalaman itu hanya dapat dijelaskan melalui praktik secara langsung dengan melakukannya sendiri, sehingga dapat merasakan apa yang dirasakan orang lain. Pengalaman terdalam dari sesuatu aktivitas tadi sifatnya sangat privat, dan hanya mampu dipahami oleh pelakunya. ${ }^{24}$ Pengalaman terdalam inilah yang menjadi dasar awal untuk memahami istilah inward experience dalam kajian ini.

Jika merujuk pada tulisan Adams, ditemukan penjelasan untuk istilah inward experience tersebut. Ia menjelaskan bahwa inward experience adalah dimensi batin dalam agama, suatu wilayah kesadaran, perasaan dan tanggung jawab yang besifat personal atau tidak dapat dikomunikasikan melalui tulis maupun lisan. Area ini hanya dapat diakses secara parsial oleh seseorang dan sering tidak dapat diakses secara keseluruhan. Hanya pelakunya (insider) yang mampu memahaminya. Sementara outward behaviour menurut Adams adalah manifestasi eksternal agama yang dapat diamati dan dikomunikasikan,

23 Taufik Abdullah dan M. Rusli Karim (eds.), Metodologi Penelitian Agama: Sebuah Pengantar (Yogyakarta: Tiara Wacana, 1990), 92.

24 'Âmir al-Najjâr, al-Ṭruq al-Ṣ̂́fìah fî Miṣr (Kairo: Dâr al-Kutub al-'Ilmîyah, 2010), 39. 
dapat dijangkau oleh orang lain (outsider) karena area ini bersifat eksternal yang tampak oleh kasat mata. ${ }^{25}$

Banyak sekali tawaran-tawaran istilah yang telah dimunculkan oleh para sarjana, terkait dengan dua model pendekatan di atas. Dalam bahasa Arab, dua istilah di atas (inward experience dan outward behaviour) dapat disebut dengan istilah al-zâhir (untuk outward behaviour) dan albâtin (untuk inward experience). Streng dalam Understanding Religious Life menggunakan istilah pengalaman objektif (objective experience) untuk outward behaviour dan pengalaman subjektif (subjective experience) untuk inward experience. Menurutnya, hakikat agama itu terletak pada pengalaman keagamaan seseorang (inward experience), sehingga agama dipahami secara berbeda oleh masing-masing pemeluknya sesuai dengan perasaannya yang terdalam (deepest personal feelings). ${ }^{26}$

Dengan istilah yang mirip, Amin dalam acara AICIS XIV di Samarinda menyebut istilah subjectivity of religiousity dalam rangka menjelaskan pengalaman keagamaan internal, dan objectivity of religiousity untuk perilaku eksternal. ${ }^{27}$ Sementara pada makalah yang pernah penulis presentasikan pada AICIS XII di Surabaya, penulis memunculkan istilah eksoteris dan esoteris, meskipun penggunaan dua istilah itu penulis gunakan untuk konteks yang lain. Tetapi istilah eksoteris dan esoteris juga dapat digunakan sebagai alat bantu dalam memahami konsep inward experience dan outward behaviour yang dimaksud pada tulisan ini. Bahwa inward experience dapat kita kategorikan ke dalam aspek esoteris (aspek dalaman), sementara outward behaviour dapat kita kategorikan aspek eksoteris (aspek luaran). ${ }^{28}$

Istilah yang lain juga ditemukan dalam kajian yang dilakukan oleh Bassam Tibi, ketika menggunakan istilah models of reality dan models for reality. ${ }^{29}$ Aspek eksternal (outward behaviour) komunitas beragama lebih dekat dengan konsep models of reality, sementara aspek internal (inward experience) pada diri komunitas beragama lebih dekat dengan konsep models for reality. Wilfred Cantwell Smith juga mengusulkan dua

25 Adams, "Islamic Religious Tradition", 40.

${ }^{26}$ Frederick J. Streng, Understanding Religious Life (California: Wadsparth Publishing Company, 1985), 1-2.

27 Abdullah, "The Intersubjective Type of Religiousity".

${ }^{28}$ Hammis Syafaq, "Integrasi Pengetahuan Islam Eksoteris dan Esoteris dalam Kajian Islam”, dalam Proceeding AICIS XII di Surabaya tahun 2012.

${ }_{29}$ Bassam Tibi, Islam and the Cultural Acommodation of Social Change (Oxford: Westview Press, 1991), 8. 
pendekatan di atas untuk kajian agama meskipun dengan menggunakan istilah yang berbeda, yaitu tradition dan faith. ${ }^{30}$ Tradition adalah aspek eksternal keagamaan, aspek sosial dan historis agama yang dapat diobservasi dalam masyarakat. Sementara faith adalah aspek internal yang tidak dapat tersampaikan melalui penjelasan kata, memiliki orientasi transenden, dan berdimensi pribadi dalam kehidupan beragama. ${ }^{31}$

Menarik sekali menggunakan pendekatan pengalaman batin (inward experience) dan perilaku eksternal (outward behaviour) dalam kajian agama karena Abu Rabi' mengatakan bahwa agama ketika menjadi realitas sosial, mengalami perubahan secara historis. ${ }^{32}$ Perubahan itu, menurut Yinger, seiring dengan perubahan pemahaman penganutnya dan latar belakang sosialnya yang berbeda (inward experience). ${ }^{33}$ Untuk itulah penulis setuju dengan Smith ketika ia mengatakan bahwa Islam (agama) adalah produk sejarah yang sangat dinamis. ${ }^{34}$ Oleh Shahrûr realitas Islam yang berkembang itu disebut dengan istilah al-Islâm altârikhî (Islam historis), yaitu Islam yang terbentuk melalui perjalanan waktu yang cukup panjang dan dipengaruhi oleh kondisi sosial, politik, dan aliran pemikiran yang ada di sekitarnya. ${ }^{35}$

Penjelasan yang dapat digunakan untuk membantu memahami teori Smith dan Shahrûr di atas adalah tulisan Tibi, yang menyatakan bahwa Islam yang diturunkan di tengah bangsa Arab telah diadopsi oleh masyarakat non-Arab dengan kultur yang berbeda, sehingga dalam memahami ajaran Islam masing-masing memiliki perbedaan. Dari perbedaan itu muncul banyak corak Islam. Ada Islam Iran, Islam Indonesia, Islam Afrika, dan lain sebagainya. Masing-masing varian mempresentasikan dimensi budayanya sesuai dengan interpretasi mereka terhadap ajaran Islam. ${ }^{36}$ Maka dapat dipahami jika Tothven

\footnotetext{
30 Adams, "Islamic Religious Tradition", 35.

31 Ibid., 33.

32 Ibrahim M. Abu Rabi', Intellectual Origins of Islamic Resurgence in the Modern Arab World (New York: Oxford University Press, 1996), 1.

33 Milton Yinger, The Scientific Study of Religion (New York: Mac Milton Pub, 1970), 20.

34 Wilfred Cantwell Smith, Religious Diversity (New York: Harper dan Row, 1982), 120.

35 Muhammad Shaḥrûr, Naḥw Ușûl Jadîdah li al-Figh al-Islâmî (Damaskus: al-Ahâlî, 2000), 2.

36 Bassam Tibi, The Crisis of Modern Islam (Salt Lake City: University of Utah Press, 1988), 4.
} 
menyebutkan bahwa ada perbedaan antara ajaran ideal Islam dengan praktik yang terjadi di lapangan. ${ }^{37}$

Uraian di atas menjadi penguat bagi kita untuk sepakat dengan pernyataan Smith yang menyebutkan bahwa visi Islam ketika ia berkembang ke berbagai negara dengan budaya yang berbeda, tidak akan sama dari satu tempat ke tempat lainnya, atau dari satu waktu ke waktu yang lainnya. ${ }^{38}$ Perbedaan itu terjadi karena ketika ajaran Islam bersentuhan dengan masyarakat, ia membentuk suatu tradisi kultural. Tradisi kultural itu pun kemudian dengan sendirinya tumbuh dan berubah. $^{39}$

Maka, kebenaran agama bisa saja diklaim sebagai kebenaran holistik, tetapi kualitas dan pengalaman keberagamaan seseorang tetap dalam ranah relatif dan selalu berubah. Meskipun relatif, keberagamaan seseorang tetap selalu melibatkan sikap emosional. Tanpa emosi dan keyakinan tidak akan ada keberagamaan. ${ }^{40}$

Memperkuat uraian di atas, penulis harus menyebut pernyataan Shahrûr di bawah ini:

Jika kami katakan, carilah Islam di seluruh pelosok dunia, carilah yang sama persis seperti masa Nabi, maka di saat seluruh dunia sudah diteliti, anda belum bisa duduk, karena belum menemukan sesuatu yang dicari. Bagaimana kita dapat menemukan Islam pada umat yang sejak awal tidak percaya bahwa Muhammad adalah utusan Allah. Jika masalahnya tidak begini dan tidak begitu, maka di mana kita mencari Islam? Bagaimana mencarinya? Di al-Azhar, al-Zaytûn, Najf, Makkah, Qûm, Baghdâd, atau Quds? Apakah kita mencari Islam dengan cara pandang Imam al-Shâfî̀ atau Imam Mâlik? Atau dengan cara pandang kita saat ini? Apakah kita memahami Islam melalui kitab-kitab atau realitas? Jika melalui realitas, realitas mana yang dimaksud? Realitas abad ke-7 ataukah abad ke-20?). ${ }^{41}$

Dalam pandangan Shahrûr, jika ada yang menghendaki agar realitas Islam abad ke-21 ini disamakan dengan realitasnya di abad ke7, maka ia seperti memutar mundur roda sejarah, yang berarti ia

${ }^{37}$ Malise Rothven, Islam in the World (Oxford: Oxford University Press, 1984), 354.

38 Wilfred Cantwell Smith, The Meaning and End of Religion (t.t.: New English Library, 1966).

${ }^{39}$ Marshall G. S. Hodgson, The Venture of Islam, Vol. 3 (Chicago: The University of Chicago Press, 1974), 112.

${ }^{40}$ Komaruddin Hidayat, "Kata Pengantar", dalam Zainuddin Maliki, Agama Rakyat, Agama Penguasa (Yogyakarta: Yayasan Galang, 2000), ix.

${ }^{41}$ Shahrûr, Naḥw Usûul Jadîdah, 2. 
melupakan perjalanan sejarah yang terus berkembang dan tidak pernah berhenti. Memutar mundur roda sejarah sama dengan menentang takdir Allah. ${ }^{42}$ Ini berarti bahwa kajian agama harus berbasis pada realitas yang terjadi di masyarakat, sehingga tidak hanya berbasis pada apa yang ada di teks.

Penulis sependapat dengan Daniel L. Pall yang menyatakan bahwa kepercayaan terhadap Yang Maha Hidup adalah esensi dari semua agama. ${ }^{43}$ Artinya, dalam beragama, konsepsi-konsepsi manusia tidak didasarkan pada pengetahuan, tetapi pada kepercayaan kepada Yang Maha Kuasa. ${ }^{44}$ Kepercayaan itu muncul karena adanya harapan untuk memperoleh keselamatan eskatologis dari orang beragama. ${ }^{45}$ Tetapi harus disadari bahwa menjalankan ajaran Islam dari al-Qur'ân dan Hadîth tidak selalu dapat dilakukan melalui pendekatan rasionalisasi Weberian, atau dengan melakukan pemutusan secara radikal terhadap tradisi dan konteks sosial-budaya, karena islamisasi tidak selamanya berarti rasionalisasi sebagaimana yang dikemukakan oleh Geertz. ${ }^{46}$ Alasannya adalah bahwa pemahaman seseorang terhadap agama antara satu dengan yang lainnya dapat berbeda, karena pemahaman itu bersifat subjektif sesuai dengan batas kemampuan dan wawasan masing-masing, yang keduanya termasuk dalam aspek inward experience.

Sesungguhnya inti dari dua model pendekatan pengalaman batin (inward experience) dan perilaku eksternal (outward behaviour) dalam tulisan ini adalah memahami aspek perasaan dan pengalaman dari pemeluk agama yang bersangkutan (believer) yang oleh Amin diistilahkan dengan cara memahami model keberagamaan seseorang melalui pendekatan outsider. $\mathrm{Di}$ sinilah poin penting dalam menjelaskan model pendekatan pengalaman batin (inward experience) dan perilaku eksternal (outward behaviour) dalam kajian agama pada tulisan ini.

\section{Pendekatan Inward Experience dan Outward Behaviour}

Dalam ayat al-Qur'ân disebutkan bahwa Allah tidak pernah memaksa hamba-Nya untuk memiliki satu bentuk pemahaman tentang ajaran Islam, karena kemampuan manusia dalam

42 Ibid.

${ }^{43}$ Daniel L. Pall, Seven Theories of Religion (New York: Oxford University Press, 1996), 24

${ }^{44}$ Tibi, Islam and Cultural, 8.

${ }^{45}$ Hidayat, "Kegagalan Peran Sosial Agama", xi.

46 Baca Clifford Geertz, Santri, Priyayi, Abangan dalam Masyarakat Jawa, terj. Aswab Mahasin (Jakarta: Pustaka Jaya, 1981). 
melaksanakan suatu ajaran agama sangat terbatas. ${ }^{47}$ Dalam al-Qur'ân juga dijelaskan bahwa Allah memberikan kemudahan kepada umat manusia dalam melaksanakan suatu ajaran agama. Tujuannya, agar ajaran agama berada dalam daya dan kemampuan manusia, sehingga dapat dilaksanakan dan bermanfaat bagi manusia.

Sepintas, pernyataan ini mengisyaratkan adanya intervensi manusia dalam urusan yang menjadi hak prerogatif Allah. Maka, agar tidak muncul kesan adanya intervensi itu, harus dibedakan antara agama dan pemahaman terhadap agama, atau antara Islam dan tradisi Islam. Agama (Islam) adalah ajaran yang bersifat absolut, karena besumber pada teks al-Qur'ân dan Hadîth, sementara pemahaman keagamaan (tradisi Islam) adalah hasil karya manusia melalui interpretasi terhadap kedua sumber tersebut. ${ }^{48}$

Al-Qur'ân sebagai Kitab Suci umat Islam yang menganut mazhab apapun, ciri universalnya terbatas pada tingkat teks. Tetapi pada saat menjadi operasional dalam kehidupan manusia, teks itu diinterpretasikan maknanya dan dipahami oleh para pemeluknya secara berbeda. Hasil interpretasi yang berbeda itu kemudian menjadi pedoman sakral atau suci bagi kehidupannya. ${ }^{49}$ Perbedaan interpretasi terhadap teks al-Qur'ân muncul karena al-Qur'ân tidak sekadar teks, tetapi diyakini sebagai firman Allah, di mana meskipun maknanya dapat disampaikan dalam bahasa lain, tetapi teks itu sendiri tidak bisa diterjemahkan, hanya Arab aslinya yang merupakan firman Allah. ${ }^{50}$

Al-'Ashmâwî, dalam tulisannya, menyatakan bahwa Nabi Muhammad tidak pernah menuntut pengikutnya untuk merealisir semua ide-ide Islam secara tepat sama dengan yang beliau lakukan. ${ }^{51}$ Artinya, wajar jika terdapat perbedaan bentuk antara Islam di masa sekarang dengan Islam di masa lampau. Perbedaan bentuk antara Islam di masa sekarang dengan Islam di masa lampau ini juga ditemukan dalam perbedaan bentuk pemikiran fiqh dalam komunitas yang beragam.

Oleh karena itu, meskipun Islam tumbuh dalam tradisi dan masyarakat Arab, tetapi umat Islam tidak harus menerjemahkannya

47 al-Qur'ân, 2: 286.

48 Muḥammad Saî̀d al-'Ashmâwî, Jawhar al-Islâm (Kairo: Maktabah Madbûlî, 1996), 91-97.

49 Parsudi Suparlan, "Kata Pengantar", dalam Harisun Arsyad (ed.), Ketakwaan tehadap Tuhan Yang Maha Esa (Jakarta: DEPAG RI, 2000), xv-xx.

${ }^{50}$ Mark R. Woodward, Islam Jawa (Yogyakarta: UMI, 1985). 119.

51 al-'Ashmâwî, Jawhar al Islâm, 97. 
sesuai dengan yang diterapkan oleh masyarakat Arab. Umat Islam dapat memberikan formula sesuai dengan kondisi sosialnya. Frederick dalam penelitiannya menyebutkan bahwa praktik keagamaan yang dilakukan oleh pemeluk agama adalah bentuk ekspresi dari doktrin agama yang dipahami oleh pemeluknya. ${ }^{52}$ Antara ritual atau praktik keagamaan dan doktrin, keduanya saling menguatkan dalam proses beragama.

Penjelasannya adalah bahwa tauhid atau keyakinan bukan sekadar proposisi teologis, tetapi juga realisasi manusia dalam mengesakan Tuhan dengan ketaatan dan ketundukan total. Demikian juga dengan rukun Islam, ia menjadi kategori utama dari model keyakinan seorang Muslim dalam beragama. ${ }^{53}$ Maka, perbedaan model ritual atau praktik keagamaan adalah bagian dari bukti fisik untuk perbedaan keyakinan pemeluk agama. Hanya saja Frederick melihat bahwa yang sering menjadi masalah dalam studi tentang ritual atau praktik keagamaan adalah terjadinya konflik antara pendekatan normatif dan deskriptif dalam analisa perilaku. ${ }^{54}$

Teori yang berkembang dalam studi tentang ritual atau praktik keagamaan adalah teori yang menggunakan sumber teks sebagai alat analisis untuk melihat bentuk ritual atau praktik keagamaan. Teori ini memunculkan model Islam resmi/Islam normatif. Teori yang kedua dan teori yang menggunakan sumber konteks sebagai alat analisis untuk melihat bentuk ritual atau praktik keagamaan. Teori ini memunculkan model Islam populer. ${ }^{55}$

Padahal, menurut Frederick, praktik ritual keagamaan bagi partisipan atau pelakunya adalah bagian dari upaya untuk menghidupkan kembali kebenaran terdalam yang ada pada dirinya, ${ }^{56}$ sehingga penggunaan teori pertama (pendekatan Islam normatif) tidak dapat digunakan sebagai model analisis untuk kondisi terdalam yang ada pada diri pelaku agama itu. Oleh sebab itu, Frederick dalam

\footnotetext{
52 Frederick M. Denny, "Islamic Ritual: Perspectives and Theories", dalam Richard C. Martin, Approaches to Islam in Religious Studies (USA: Arizona State University, 1985), 64.

53 Ibid., 69.

${ }^{54}$ Kesulitan ini dipaparkan oleh J.D.J. Waardenburg dalam tulisannya yang berjudul Official and Populer Religion as a Problem in Islamic Studies (Paris: Mouton Publisher, 1979), 218.

55 Hammis Syafaq, Islam Populer dalam Masyarakat Perkotaan (Yogyakarta: Impulse, 2011).

${ }^{56}$ Denny, "Islamic Ritual”, 66.
} 
bukunya Islamic Ritual, mengritisi model pertama ini. Menurutnya, model ini bagian dari pengabaian studi sistematik tentang ritual Islam, ${ }^{57}$ karena hanya bersumber dari teks-teks resmi (kitâbah), tidak dari hasil riblah. ${ }^{58}$

Masksud dari istilah rị̣lah di sini adalah bahwa kajian agama melalui proses pengalaman yang dilakukan dengan pengamalan. Dalam teori sosiologi mirip dengan pendekatan fenomenologi, yaitu kajian keagamaan yang melibatkan peneliti di dalamnya. Melihat model keberagamaan orang lain melalui inward experience, bukan outward behaviour.

Menurut Charles J. Adams, ada dua hal yang diperlukan untuk memahami pendekatan fenomenologis. Pertama, fenomenologi diartikan sebagai metode memahami agama orang lain dengan cara menempatkan diri pada posisi netral. Fenomenologi digunakan untuk menerapkan metode dalam meletakkan pandangan subjektif peneliti. Kedua, sebagai konstruksi skema dalam menglasifikasikan fenomena dengan melintasi batas-batas komunitas agama, budaya dan zaman. Intinya adalah mencari esensi, makna dan struktur pengalaman keagamaan manusia secara keseluruhan. Dalam pengalaman keberagamaan manusia ada esensi yang irreducible dan itulah struktur fundamental manusia beragama. ${ }^{59}$

Prestasi besar pendekatan fenomenologis adalah adanya keniscayaan pandangan bahwa norma dari semua studi tentang agama adalah pengalaman kaum beriman itu sendiri. Oleh karena itu, kepentingan dasar yang menjadi soal fenomenologi ini adalah terkait dengan pertanyaan apa yang telah dialami, dirasakan, dikatakan, dan dilaksanakan oleh orang beragama itu sendiri, terutama pengalamanpengalaman yang bermakna bagi pemeluknya.

Dengan demikian, tujuan dari studi fenomenologi adalah untuk menjelaskan makna-makna sehingga memperjelas apakah ritus, seremoni, doktrin atau reaksi sosial itu mengandung arti bagi pelakunya dalam peristiwa keagamaan. Selain itu, fenomenologi menghendaki agar untuk memberikan makna terhadap fenomena

\footnotetext{
${ }^{57}$ Ibid., 63.

58 Ibid.

${ }^{59}$ Uraian lengkap tentang fenomenologi ini bisa ditemukan dalam M. Zainuddin, "Richard C. Martin: Pendekatan dalam Studi Islam", Makalah Kelas Program S-3 IAIN Sunan Ampel Surabaya, 2003.
} 
keagamaan secara memadai, maka seorang peneliti dituntut berpikir secara komprehensif. ${ }^{60}$

Kajian fenomenologi berupaya untuk memahami makna keagamaan yang ada dalam pemeluknya dengan menganalisa. Ia merupakan pendekatan yang memiliki sikap terbuka dan empati (open and empathetic approaches). Pendekatan fenomenologis berupaya untuk memanifestasikan agama melalui metode deskripsi murni, di mana penilaian peneliti tentang nilai dan kebenaran ditangguhkan (epoche), objek ditangkap esensinya (eidetic vision), agama tidak dipandang sebagai satu tahapan dalam sejarah evolusi, tetapi lebih sebagai aspek hakiki dari kehidupan manusia (essential aspect of human life), keragaman ekspresi perilaku keagamaan manusia dipilih dan disaring. ${ }^{61}$

Komponen metodologis terpenting dalam kajian fenomenologi adalah das Vestehen, karya W. Dilthey, suatu istilah teknik yang berarti pemahaman tentang gagasan, intensi dan perasaan orang/masyarakat melalui manifestasi-manifestasi empirik dalam kebudayaan. Metode Vestehen mengandaikan bahwa manusia di seluruh masyarakat dan lingkungan sejarah mengalami kehidupan yang bermakna (meaningfull) dan mengungkapkan makna itu dalam pola-pola yang dapat dilihat (discernible patterns), sehingga dapat dianalisis (can be analyzed) dan dipahami (understood). ${ }^{62}$ Maka berpikir fenomenologis harus memiliki dua kaki; the comprehension of ideas, intentions, feeling of people, dan the empirical manifestation of culture.

Menarik sekali pernyataan A.J. Wensinck, dalam artikel panjangnya berjudul "haij", pada edisi kedua The Encyclopedia of Islam, terkait masalah pengaruh spiritual haji. Ia mengatakan "hanya Tuhan saja yang tahu". Pernyataan ini adalah bagian dari kritik terhadap kajian keagamaan yang hanya fokus pada aspek luaran (outward behaviour) tadi. ${ }^{63}$

Pendekatan inward experience dan outward behaviour dijadikan sebagai tawaran model dalam tulisan ini karena penulis menemukan dengan jelas kasus di lapangan dari apa yang pernah disampaikan oleh Richard C. Martin dalam bukunya, Approaches to Islam in Religious Studies, bahwa banyak dari bentuk praktik keagamaan yang tidak didapatkan dalam sumber-sumber resmi, tetapi dipraktikkan oleh komunitas Muslim. ${ }^{64}$

\footnotetext{
${ }^{60}$ Ibid.

${ }^{61}$ Ibid.

${ }^{62}$ Ibid.

${ }^{63}$ Roff, "Pilgrimage and the History of Religions", dalam Martin, Approaches, 78-79.

${ }^{64}$ Ibid., 61.
} 
Sementara praktik keagamaan itu merupakan aktivitas-aktivitas simbolik yang memiliki signifikansi yang amat besar bagi pemeluknya. Ambil contoh mengunjungi makam para wali yang dilakukan beberapa komunitas Muslim dalam rangka untuk mendapatkan barakah. Bentuk praktik itu jika dibaca dalam karya Ibn Taymîyah atau Wahhâbîyah, dianggap menyimpang dan ditambah-tambahkan. ${ }^{65}$

Menariknya, meskipun dapat serangan hebat dari Ibn Taymîyah, Wahhâbîyah, dan yang lainnya, praktik keagamaan itu (kunjungan ke makam wali) tidak pernah dapat dimusnahkan. Praktik keagamaan yang oleh Wahhâbîyah dianggap menyimpang itu masih terus dilakukan oleh beberapa komunitas Muslim yang "menikmatinya", bahkan memandangnya sebagai bagian penting dari menjadi Muslim. Maka, merujuk pendapat Frederick, yang dibutuhkan dalam studi tentang praktik ritual keagamaan adalah perhatian yang lebih peka terhadap perasaan terdalam yang dimiliki oleh pelakunya (inward experience). ${ }^{66}$

Hal ini penting untuk disampaikan karena menurut Roff, fenomena yang terjadi di masyarakat Muslim itu membutuhkan alatalat analisis yang dapat menangkap apa yang ada di balik perilaku keagamaan itu. Caranya, dengan menggambarkan sesuatu dari praktikpraktik yang diteliti dan gagasan-gagasan para pemeluk agama, dari suatu proses sosial yang terstruktur, dan mendapat pengakuan dari pemeluk-pemeluknya. ${ }^{67}$ Menurut Roff hal itu penting dilakukan dalam rangka menemukan hakikat makna dari penampakan model keagamaan sebagaimana yang dipahami dan dipraktikkan oleh pemeluknya. ${ }^{68}$

Titik poin dari kajian ini adalah menekankan bahwa memiliki agama bukan dimaksudkan sebagai memahami agama, dan memahami agama tidak sama dengan mempercayainya. Memeluk agama adalah menemukan dunia lain untuk hidup pada dirinya sendiri. Upaya itu bukan wilayah kajian ilmiah, karena kajian agama tidak sama dengan memiliki agama. Kajian agama harus dilakukan dengan upaya menangkap esensi dari perilaku keagamaan, yang menuntut upaya simpati dan inklusif pada sumber-sumber dalam bentuk manusia, yang memahami makna bagi perilakunya. ${ }^{69}$

${ }^{65}$ Denny, "Islamic Ritual", 64.

${ }^{66}$ Ibid., 65.

${ }^{67}$ Roff, "Pilgrimage and the History of Religions", dalam Martin, Approaches, 78-79.

68 Ibid., 79.

${ }^{69}$ Ibid., 66-67. 
Hal inilah yang menjadi concern dari kerangka kerja model pendekatan pengalaman batin (inward experience) dan perilaku eksternal (outward behaviour) dalam kajian agama di sini, yaitu memadukan teks, yang dijadikan pijakan umat Islam dalam melaksanakan ajaran agamanya, dengan konteks, yang membentuk model pengalaman umat Islam dalam beragama. Maka dua pendekatan di atas sebetulnya mengusulkan adanya model analisis terhadap praktik keagamaan dengan cara memahami dan menghargai sifat keyakinan yang khas dari model ritual keagamaan. ${ }^{70}$

Kerangka kerja model pendekatan ini adalah memahami model keberagamaan orang lain tidak hanya dengan melihat aspek eksternal yang tampak dari apa yang dilakukan oleh orang lain itu, tetapi dengan memahami aspek internal dari apa yang dirasakan oleh orang lain ketika ia melakukan aktivitas keagamaannya. Jika meminjam istilah Amin Abdullah adalah tidak hanya menggunakan aspek subjectivity tetapi juga aspek objectivity. ${ }^{71}$

Model ini penulis tawarkan untuk kajian agama, karena ditemukan kasus di lapangan adanya perbedaan pengalaman beragama yang berdampak pada terjadinya perbedaan perilaku keagamaan. Kasus yang dapat disebutkan di sini adalah perbedaan antara tiga kiai NU di Jawa Timur, yaitu Kiai Luthfi Bashori, Pengasuh Pesantren Ribat alMurtada al-Islami Singosari Malang, Kiai Muhyiddin Abdussomad, Pengasuh Pondok Pesantren Nurul Islam Jember, dan Kiai Ahmad Asrori Utsman al-Ishaqy, Pengasuh Pondok Pesantren al-Fitrah di Kedinding Lor, Kecamatan Kenjeran, Kota Surabaya. ${ }^{72}$

Ketiga kiai itu memiliki perbedaan perilaku kegamaan (outward behaviour) yang disebabkan oleh perbedaan pengalaman pengembangan keilmuannya, antara bidang aqidah, fiqh, dan tasawuf. Kiai Luthfi Bashori yang melakukan pengembangan keilmuan di bidang aqidah menjadi aktif di gerakan sosial keagamaan, seperti FPI (Front Pembela Islam) dan MMI (Majelis Mujahidin Indonesia).

Kiai Muhyiddin Abdussomad yang melakukan pengembangan keilmuan di bidang fiqh menjadi aktif di gerakan NU-kultural, seperti penerbitan buku-buku tentang Aswaja NU dan dialog-dialog pemikiran. Kiai Ahmad Asrori Utsman al-Ishaqy, pimpinan pesantren

${ }^{70}$ Ibid.

${ }^{71}$ Abdullah, "The Intersubjective Type of Religiousity".

72 Ma'shum, "Teologi Ahl al-Sunnah wa al-Jamâ'ah dalam Konstruksi Kiai Nahdlatul Ulama Jawa Timur: Kajian Sosio-Teologis" (Disertasi--PPs IAIN Sunan Ampel, 2009). 
al-Fitrah, yang melakukan pengembangan keilmuan di bidang tasawuf menjadi aktif di gerakan perbaikan moral dengan kegiatan tarekatnya dalam bentuk zikir bersama. ${ }^{73}$

Begitu juga dengan hasil penelitian penulis tentang praktik keagamaan yang populer di kalangan Nahdliyyin (masyarakat NU). Ada beberapa praktik keagamaan yang oleh beberapa kelompok puritan diklaim sebagai bid'ah tetapi tetap semarak dilakukan. Faktor yang melatari semaraknya perilaku keagamaan itu adalah karena adanya pengalaman luar biasa yang dirasakan oleh pelakunya, dalam bentuk kenikmatan spiritual. ${ }^{74}$

Maka penelitian tentang agama, terutama terkait dengan suatu model keberagamaan, perlu dilakukan dari dua sudut di atas, yaitu sudut normatif dan sudut nyata, sudut internal dan sudut eksternal, sudut inward experience dan sudut outward behaviour. Alasannya adalah bahwa apa yang dikemukakan oleh agama secara normatif dengan apa yang dilakukan oleh umat beragama tidak pasti identik. Situasi kejiwaan tertentu selalu saja muncul dalam diri individu dalam beragama.

Situasi kejiwaan itu sangat dipengaruhi oleh hasil pengalaman pribadi pemeluk agama dalam mengaplikasikan ajaran agamannya. Pengalaman pribadi inilah yang penulis sebut dengan istilah inward experience. Tentu saja pengalaman yang dialami seseorang berbeda dengan yang dialami orang lain, terutama ketika terkait dengan pengalaman berhubungan dengan Tuhannya, baik dalam hal pengalaman ritual, maupun pengalaman perjuangan harapan. Pengalaman itu tidaklah dibuat-buat, tetapi bersifat spontan karena perasaan tertentu seperti cemas, takut, menghadapi kesulitan, ikut berperan dalam membentuk model sikap keberagamaan seseorang.

Dengan demikian, ibadah seseorang kepada Tuhan sangatlah privat atau esoteris, sehingga sulit diukur kualitasnya oleh orang lain atau lembaga keagamaan yang paling otoritatif sekalipun. Sementara, lembaga-lembaga keagamaan lebih cenderung menyentuh dimensi eksoterik agama saja ketika melihat kelompok beragama. Jika tidak menggunakan pendekatan inward experience dalam kajian agama, maka aspek internal pada diri pelaku ajaran agama tidak dapat tersentuh, tidak dapat perhatian, dan tidak menjadi pertimbangan alternatif

\footnotetext{
73 Ibid.

${ }^{74}$ Syafaq, Islam Populer, 211. 
dalam menyikapi model keberagamaan yang beragam di tengah komunitas beragama di sekitar kita.

Dalam rangka itulah penulis berpendapat bahwa pendekatan inward experience dan outward behaviour ini sebagai tawaran model untuk kajian agama sebagaimana yang pernah ditawarkan juga oleh Amin Abdullah dalam bentuk pendekatan beleiver/insider dan pendekatan bistorian/outsider. ${ }^{75}$ Tujuan dari tawaran dua model ini adalah dalam rangka melengkapi model kajian Islam yang sedang berkembang saat ini, yaitu pendekatan fideistic subjectivism/al-'aql al-dîn $\hat{\imath}$ al-lâhûtî (pemikiran teologis-normatif), dan yang kedua menggunakan pendekatan scientific objectivism/al-'aql al-falsafi (pemikiran saintifik). ${ }^{76}$ Tawaran dua model ini (inward experience dan outward behaviour) adalah dalam rangka mendukung pendekatan scientific objectivism/al-'aql alfalsafî.

Harapannya adalah agar Islam tidak hanya dipahami dari teks yang tertulis, tetapi juga melalui konteks. Eksperimen model Islam di Madinah yang dipimpin oleh Nabi Muhammad merupakan eksperimen yang sempurna, karena tidak terlepas dari interaksi teks alQur'ân yang masih berbentuk oral dengan Nabi Muhammad dan komunitas Madinah. Sementara kita sekarang hidup di zaman yang berbeda, dan teks oral telah berhenti dan berubah menjadi teks tulis. ${ }^{77}$ Tugas kita sekarang adalah menggabungkan antara teks tulis dengan konteks kekinian. Antara wahyu yang irasional dengan realitas yang rasional. Oleh karena itulah, dalam mengkaji agama kita perlu merujuk kepada pemahaman pelakunya.

\section{Penutup}

Kajian tentang agama terus berkembang, apalagi di perguruan tinggi Islam seperti UIN, IAIN, STAIN, dan sejenisnya. Pendekatanpendekatan baru juga terus berkembang seiring dengan berkembanganya kajian agama dan problem-problem kemanusiaan yang bersentuhan dengan agama. Inward experience dan outward behaviour adalah bagian dari model pendekatan dalam kajian agama yang menawarkan untuk memahami perasaan orang lain dalam beragama. Tidak hanya melihat bentuk formal-eksternal dari perilaku keagamaan

75 M. Amin Abdullah, Studi Agama: Normativitas atau Historisitas (Yogyakarta: Pustaka Pelajar, 2002), 61.

${ }^{76}$ Sharpe, Comparative Religion of History, 313.

77 Muhammad Arkûn, al-'Almanah wa al-Dîn, terj. Hâsim Ṣâlih (Beirut: Dâr al-Sâqî, 1996). 
seseorang, karena aspek eksternal belum tentu sama dengan aspek internal.

Model ini menjadi tawaran alternatif dalam melihat model keberagamaan orang lain agar kita selaku pemeluk agama tidak terjebak ke dalam sikap intoleransi kepada mereka yang berbeda dengan model keberagamaan kita. Masing-masing dari pelaku ajaran agama memiliki pengalaman yang berbeda karena perasaan kita berbeda antara satu dengan yang lainnya. Ada kekhususan pada wilayah pengalaman sesuai dengan kapasitas kepuasaan yang dicapai oleh masing-masing kelompok beragama.

Wilayah pengalaman itu dapat juga disebut sebagai petualangan spiritual, yaitu suatu perjalanan batin, suatu drama psikis, penjelajahan hati, doktrin, disiplin kontemplatif. Wilayah ini tidak dapat dikomunikasikan, tidak dapat diserap, dan tidak dapat ditransfer. Wilayah ini berbeda dari kehidupan eksternal penganut agama yang dibentuk oleh kekuatan/kehidupan di luar jiwa, kekuasaan politik, urusan duniawi, hubungan sosial. Hampir semua orang tidak dapat melarikan diri dari zaman dan sesuatu yang ada di luar jiwanya. Semua kekuatan itu menyusup ke dalam kehidupan yang tersembunyi dan ikut membentuk visi religius komunitas beragama.

Pendekatan ini bertujuan untuk membawa kita ke ranah sikap yang objektif dalam melihat model keberagamaan orang lain, karena bersimpati, berempati, adalah tujuan yang dapat dicapai dari pendekatan ini, karena pendekatan ini mencoba untuk memahami apa yang dirasakan oleh orang lain ketika ia menjadi beragama, ketika memahami ajaran agama, dan ketika melaksanakan perintah agama.

\section{Daftar Rujukan}

Abdullah, M. Amin. "Kata Pengantar", dalam Richard Martin, Pendekatan Kajian Islam dalam Studi Agama, terj. Zakiyuddin Baidhawy. Surakarta: Muhammadiyyah University Press, 2001.

----. "The Intersubjective Type of Religiosity: A Contribution (a Fresh Ijtihad) of Indonesian Islamic Studies to a Multicultural Society", Makalah dipresentasikan pada Plenary Session acara AICIS XIV di Samarinda, 2014.

-----. Studi Agama: Normativitas atau Historisitas. Yogyakarta: Pustaka Pelajar, 2002.

Abdullah, Taufik. Sejarah dan Masyarakat. Jakarta: Pustaka Firdaus, 1987. 
Abdullah, Taufik, dan Karim M. Rusli (eds.). Metodologi Penelitian Agama: Sebuah Pengantar. Yogyakarta: Tiara Wacana, 1990.

Adams, Charles J. "Islamic Religious Tradition", dalam Leonard Binder (ed.), The Study of the Middle East: Research and Scholarship in the Humanities and the Social Science. New York: A WileyInterscience Publication, 1976.

Arkûn, Muhammad. al-'Almanah wa al-Dîn, terj. Hâsim Ṣalih. Beirut: Dâr al-Sâqî, 1996.

----. al-Islâm: al-Akblâq wa al-Siyâsah, terj. Hâsim Ṣâlih. Beirut: Markaz al-Inmâ' al-Qawmî, 1990.

'Ashmâwî (al), Muhammad Saî̀d. Jawhar al-Islâm. Kairo: Maktabah Madbûlî, 1996.

----. Min Waby al-Qalam. Kairo: Dâr al Ma'ârif, 1997.

Askandar, Noor Chozin. "Pendekatan dalam Studi Islam", Makalah Kelas Program Doktor IAIN Sunan Ampel Surabaya, angkatan 2003.

Baidhawy, Zakiyuddin. "Perkembangan Kajian Islam dalam Studi Agama," dalam Richard Martin, Pendekatan Kajian Islam dalam Studi Agama, terj. Zakiyuddin Baidhawy. Surakarta: Muhammadiyyah University Press, 2001.

Denny, Frederick M. "Islamic Ritual Perspectives dan Theoris", dalam Richard C. Martin, Approaches to Islam in Religious Studies. USA: Arizona State University, 1985.

Geertz, Clifford. Abangan, Santri, Priyayi dalam Masyarakat Jawa, terj. Aswab Mahasin. Jakarta: Pustaka Jaya, 1989.

Hidayat, Komaruddin. "Kata Pengantar", dalam Zainuddin Maliki, Agama Rakyat, Agama Penguasa. Yogyakarta: Yayasan Galang, 2000.

Hodgson, Marshall G. S. The Venture of Islam, Vol. 3. Chicago: The University of Chicago Press, 1974.

Huwaydî, Fahmi. al-Tadayyun al-Manqûs. Kairo: Dâr al-Shurûq, 1997.

Mansyur, Wasid. Menegaskan Islam Indonesia. Surabaya: Pustaka Idea, 2014.

Martin, Richard C. Approaches to Islam in Religious Studies. USA: Arizona State University, 1985.

Najjâr (al), 'Âmir. al-Ṭuruq al-Ṣ̂ffìyah fì Miṣr. Kairo: Dâr al-Kutub al'Ilmîyah, 2010.

Nasution, Harun. Teologi Islam. Jakarat: UI Press, 1978. 
Nata, Abuddin. Metodologi Studi Islam. Jakarta: Raja Grafindo Persada, 2003.

Ma'shum. "Teologi Ahl al-Sunnah wa al-Jamâ'ah dalam Konstruksi Kiai Nahdlatul Ulama Jawa Timur: Kajian Sosio-Teologis". Disertasi--PPs IAIN Sunan Ampel, 2009.

Pall, Daniel L. Seven Theories of Religion. New York: Oxford University Press, 1996.

Rabi', Ibrahim M. Abu. Intellectual Origins of Islamic Resurgence in the Modern Arab World. New York: Oxford University Press, 1996.

Roff, William R. "Pilgrimage and the History of Religions", dalam Richard C. Martin, Approaches to Islam in Religious Studies. USA: Arizona State University, 1985.

Rothven, Malise. Islam in the World. Oxford: Oxford University Press, 1984.

Said, Edward W. Covering Islam. New York: Pantheon Books, 1981.

Shahrûr, Muhammad. Naḥw Ușûl Jadîdah li al-Fiqh al-Islâmî. Damaskus: al-Ahâlî, 2000.

Sharabi, Hisham. "The Scholarly Point of View: Politics, Perspective, Paradigm", dalam Hisham Sharabi (ed.). Theory, Politics, and the Arab World. New York: Routledge, 1990.

Sharpe, Eric J. Comparative Religion of History. London: Duckworth, 1986.

Smith, Wilfred Cantwell. The Meaning and End of Religion. t.t.: New English Library, 1966.

-----. Religious Diversity. New York: Harper dan Row, 1982.

Streng, Frederick J. Understanding Religious Life. California: Wadsparth Publishing Company, 1985.

Suparlan, Parsudi. "Kata Pengantar", dalam Harisun Arsyad (ed.). Ketakwaan tehadap Tuban Yang Maha Esa. Jakarta: DEPAG RI, 2000

Syafaq, Hammis. "Integrasi Pengetahuan Islam Eksoteris dan Esoteris dalam Kajian Islam", dalam Proceeding AICIS XII di Surabaya tahun 2012.

----.. "Masyarakat Muslim Indonesia dan Pembentukan Ideologi Perekat Umat", Akademika: Jumal Studi Keislaman, Vol., No. 2, Maret 2004.

-----. Islam Populer dalam Masyarakat Perkotaan. Yogyakarta: Impulse, 2011. 
Tibi, Bassam. Islam and the Cultural Acommodation of Social Change. Oxford: Westview Press, 1991.

The Crisis of Modern Islam. Salt Lake City: University of Utah Press, 1988.

Waardenburg, J.D.J. Official and Populer Religion as a Problem in Islamic Studies. Paris: Mouton Publisher, 1979.

Woodward, Mark R. Islam Jawa. Yogyakarta: UMI, 1985.

Yinger, Milton. The Scientific Study of Religion. New York: Mac Milton Pub, 1970.

Zainuddin, M. "Richard C. Martin: Pendekatan dalam Studi Islam", Makalah Kelas Program S-3 IAIN Sunan Ampel Surabaya, 2003. 